\title{
Lip and Oral Cavity Cancer Clinical Distant Metastasis TNM Finding v7
}

National Cancer Institute

\section{Source}

National Cancer Institute. Lip and Oral Cavity Cancer Clinical Distant Metastasis TNM

Finding v7. NCI Thesaurus. Code C88957.

A clinical finding about one or more characteristics of lip and oral cavity cancer, following the rules of the TNM AJCC v7 classification system as they pertain to distant metastases. 